\title{
TOTAL THYROIDECTOMY WITH CENTRAL NODE DISSECTION IS A VALUABLE OPTION IN PAPILLARY THYROID CANCER TREATMENT
}

\author{
Marija Pastorčić Grgić ${ }^{1}$, Boris Stubljar ${ }^{1}$, Pavao Perše ${ }^{1}$, Mirta Zekan Vučetić ${ }^{2}$ and Sanda Šitić3 \\ ${ }^{1}$ Division of Head and Neck Surgery, Department of Surgical Oncology, University Hospital for Tumors, \\ "Sestre milosrdnice" University Hospital Centre; \\ ${ }^{2}$ Division of Radiology, University Hospital for Tumors, "Sestre milosrdnice" University Hospital Centre; \\ ${ }^{3}$ Division of Pathology, University Hospital for Tumors, "Sestre milosrdnice" University Hospital Centre
}

\begin{abstract}
SUMMARY - Introduction: Papillary thyroid cancer is one of the cancers with favorable prognosis, although the long-term recurrence rate in the paratracheal region is reported to be as high as $30 \%$. The use of ${ }^{131} \mathrm{I}$ is considered to be a reliable treatment option for lymph node metastases in the paratracheal region. According to the majority of internationally accepted guidelines, it is not recommended to perform central node dissection (CND) routinely. Total thyroidectomy (TT) remains an adequate treatment for these patients. According to many studies, CND is associated with higher rates of hypoparathyroidism. However, CND improves staging. Methods: We performed a retrospective study. We included 248 patients treated for papillary thyroid cancer during a 20-year period. Data were collected on patient (age, sex) and tumor (size, focality) characteristics, presence of metastases in the central neck compartment, incidence of postoperative hypoparathyroidism, and locoregional failure. We divided patients into two groups based on pathological analysis: those without positive lymph nodes (N0) and those with positive paratracheal lymph nodes (N1). We compared patient and tumor characteristics and risk of recurrence between the two groups. Results: There were $39.5 \%$ patients with central neck metastases in our series. In the central neck dissection specimen, 5.5 nodes were found on average. Hypoparathyroidism was found in $23.4 \%$ of patients and remained permanent in $3.2 \%$ of patients. Female and older patients had a lower chance of central compartment metastases, as did patients with smaller and unifocal tumors. Recurrence risk was doubled for the N1 group. All tested differences between the groups reached statistical significance. Discussion and conclusion: In our hands, CND was a safe and effective surgical procedure. It improved staging and postsurgical management. Efforts should be made to improve the preoperative work-up in order to more accurately identify high-risk patients.
\end{abstract}

Key Words: differentiated thyroid cancer, total thyroidectomy, central compartment lymph node dissection

\section{Introduction}

The overall incidence of papillary thyroid cancer (PTC) is increasing, with increases in the incidence

Corresponding author: Marija Pastorčić Grgić, $\mathrm{MD}, \mathrm{PhD}$, Division of Head and Neck Surgery, Department of Surgical Oncology, University Hospital for Tumors, Sestre Milosrdnice University Hospital Centre, Ilica 197, 10000 Zagreb

E-mail: marija_pastgrgic@yahoo.com rate and thyroid cancer mortality rate for advancedstage papillary thyroid cancer ${ }^{1}$. PTC is generally considered to have a favorable prognosis ${ }^{2}$. Some authors have proposed adjustments in workup, diagnosis, and management of PTC to accommodate the discovery that many thyroid cancers are low-risk and do not require aggressive, immediate intervention ${ }^{3}$. Others have been pointing out that more than $10 \%$ of patients who died from thyroid cancer had tumors 
smaller than $2 \mathrm{~cm}$ and underwent treatment ${ }^{4}$. The problem is how to recognize the group of patients at risk for an aggressive clinical course.

Involvement of lymph nodes is very common, and, lymph node micrometastases are observed in up to $80 \%$ of cases $^{5}$. The long-term recurrence rate in the paratracheal region has been reported as being up to $30 \%$. Currently, there are no non- or minimallyinvasive methods that are completely reliable for detecting all of the metastases ${ }^{6}$. The radiological diagnostics of paratracheal space can represent a problem. It is a well-established fact that ultrasound (US) is an excellent method for assessing lateral neck compartments. Additionally, it helps guide fine needle aspiration, which is vital for diagnosis and staging. However, the identification of lymph nodes in the central compartment is not always that simple. The percentage of lymph nodes detected in this region is reported to be up to $23.9 \%{ }^{7}$ in the hands of an experienced radiologist using a high-quality highresolution ultrasound. A number of the lymph nodes go undetected due to their position beneath the thyroid gland. Furthermore, some nodes may be hard to detect because they may be overshadowed by artifacts due to bone structures or air. This is true for some nodes in region VI, and it creates a particular problem in assessing region VII involvement. As much as half of the nodes later found in surgery can be missed during the initial US examination ${ }^{8}$. The assessment can also be compromised by the quality of the ultrasound machine as well as the subjectivity of the radiologist performing the US.

During recent decades, the role of routine central lymph node dissection (CND) in the treatment of PTC has been an object of much study and remains controversial ${ }^{9}$. According to the majority of internationally accepted guidelines, it is not recommended to perform CND routinely. According to some authors, paratracheal metastases impact survival and CND lowers recurrence risk and prolongs disease free survival. Calo et al. compared rates of locoregional recurrence in patients treated with total thyroidectomy (TT) alone or in combination with bilateral or ipsilateral CND, but found no statistically significant differences between the groups ${ }^{10}$. TT with CND is associated with higher complication rates compared with TT alone, more often resulting in hypoparathyroidism than recurrence nerve palsy ${ }^{10}$. The risk-benefit analysis of neck dissection in patients with low-risk DTC showed no benefits in terms of complete remission or occurrence of progression, and risk of complications seems to be higher in patients with neck dissection ${ }^{11}$. Total thyroidectomy (TT) remains an adequate treatment for patients with PTC. The use of ${ }^{131} \mathrm{I}$ is considered a reliable treatment for lymph node metastases in the paratracheal region ${ }^{12,13}$.

CND improves staging, however. Better preoperative work-up and recognition of patients with higher risk for development of neck metastases could improve our surgical management. Ipsilateral CND could bring the benefit of better staging without burden of a rising complication rate ${ }^{6,10}$.

\section{Methods}

We performed a retrospective study. We analyzed the records of 248 patients treated for PTC at the Department of Head and Neck Surgery in the Institute for Tumors of the "Sestre milosrdnice" University Hospital during a 20-year period. We included all the patients that had preoperatively diagnosed PTC without clinical suspicion of either central or lateral neck metastases. All the patients received TT and CND. Indication for CND was based on preoperative PTC diagnosis and intraoperative finding of suspicious lymph nodes. Ipsilateral paratracheal and pretracheal spaces were routinely dissected. If any suspicious lymph nodes were observed in pretracheal or contralateral paratracheal space, contralateral dissection was also performed. All the patients received followup of at least one year. None of the patients had signs of disseminated disease during follow-up.

Data was collected on patient (age, sex) and tumor (size, focality) characteristics, number of dissected lymph nodes, presence of metastases in the central neck compartment, incidence of postoperative hypoparathyroidism, and locoregional failure. We divided patients into two groups based on pathological analysis: those without positive paratracheal lymph nodes (N0) and those with positive paratracheal lymph nodes (N1). We compared patient (age, sex) and tumor characteristics and risk of recurrence between the two groups.

Descriptive statistical methods were used to describe the study population. The chi-square test was used to test for the differences between the groups, 
except in small observed frequencies when the Yates corrected chi-square test was used. Statistical significance was set at $\mathrm{p}<0.05$.

\section{Results}

We performed TT with CND in 248 patients with PTC.

There were 150 patients (60.5\%) without and 98 patients (39.5\%) with central neck metastases.

In the whole group of patients, the mean age was 49.4 (median 51, range 11 to 86 years); 150 patients (60.5\%) were younger than 55 and 98 (39.5\%) were 55 or older. There were 48 men (19.4\%) and 200 women (80.6\%).

Average tumor size was $14.3 \mathrm{~mm}$ (median $12 \mathrm{~mm}$, range 3 to $60 \mathrm{~mm}$ ); $44.8 \%$ of tumors were up to 10 $\mathrm{mm}$ in size and $55.2 \%$ were larger than $10 \mathrm{~mm}$. The majority of tumors was unifocal (68.1\%).

CND was performed in all patients. On average, 5.5 nodes were found per CND specimen, range 0-28 per specimen, median 4. We found central neck metastases in $39.1 \%$ of patients.

Hypoparathyroidism manifested in $23.4 \%$ of patients. Eight patients (3.2\%) had permanent hypoparathyroidism requiring vitamin $\mathrm{D}$ supplements.

We observed lateral neck recurrence in 17 patients during follow-up. In this group of patients, 4 had both central compartment and lateral neck recurrence. Overall recurrence risk was $6.9 \%$.

Further analysis was performed comparing the N0 and $\mathrm{N} 1$ groups of patients.

In the N0 group of patients, we observed a higher proportion of older (70.4\%) and female patients (64\%) (Figure 1). The difference was statistically significant for both age $\left(\chi^{2}=6.168 ; \mathrm{df}=2 ; \mathrm{p}=0.013\right)$ and sex $\left(\chi^{2}=4.205 ; \mathrm{df}=2 ; \mathrm{p}=0.04\right)$. In the group of patients with tumors up to $1 \mathrm{~cm}$ in size we found metastases in $26.1 \%$ of the patients, whereas in the group of patients with tumors larger than $1 \mathrm{~cm}$ metastases were found in almost $50 \%$ of patients. The difference between the groups was statistically significant $\left(\chi^{2}=14.23 ; \mathrm{df}=2\right.$; $\mathrm{p}<0.001$ ), (Figure 2). Similarly, metastases were found in $32.5 \%$ of patients that had unifocal tumors and in $53.2 \%$ of patients with multifocal tumors. The difference between groups was statistically significant $\left(\chi^{2}=9.612 ; \mathrm{df}=2 ; \mathrm{p}=0.002\right)$ (Figure 2).

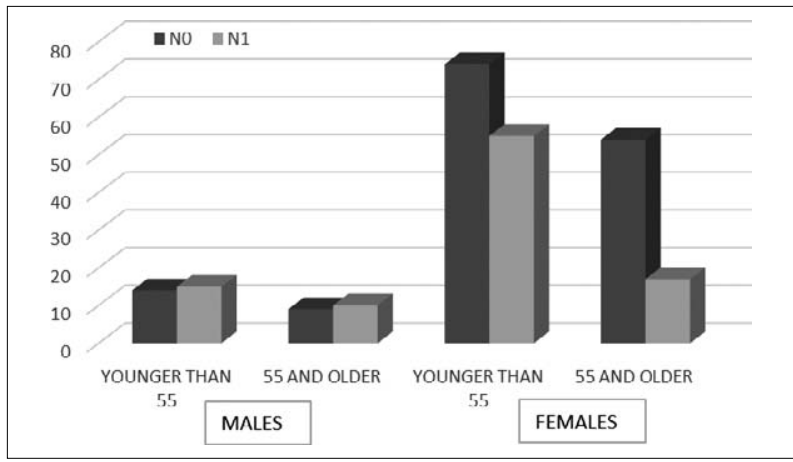

Figure 1. Patient age and sex in the NO and N1 patient groups.

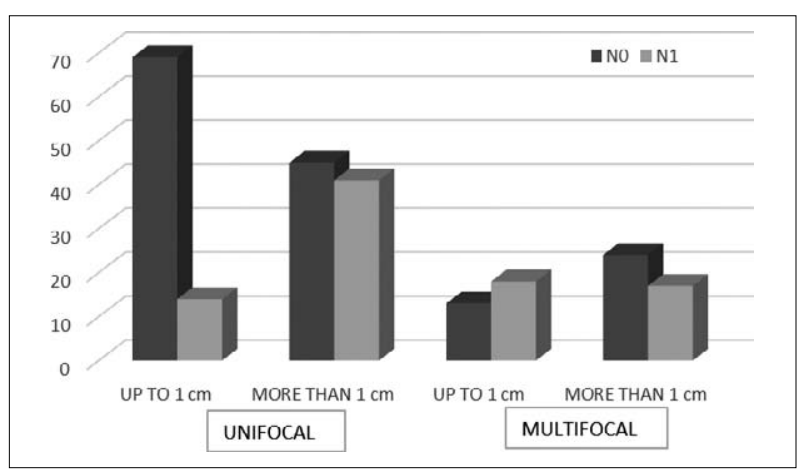

Figure 2. Size and focality of tumors in the NO and N1 patient groups.

Risk of recurrence was doubled for N1 patients, and the difference between the N0 and N1 groups was statistically significant $\left(\chi^{2}=18.49 ; \mathrm{df}=2 ; \mathrm{p}<0.001\right)$.

\section{Discussion}

Despite the overall favorable prognosis, some patients have PTC with a clinically aggressive course. Our goal was to try to identify patients who are at risk and treat them more aggressively, possibly improving the course of the disease.

Our finding of nearly $40 \%$ central compartment neck metastases in patients with PTC is consistent with literature data of $20-50 \%$ of lymph node involvement in most series. Metastases can be present even when the primary tumor is small and intrathyroidal ${ }^{14}$.

According to the literature, PTC is diagnosed in women twice as often than in men, with a median age at diagnosis of about 45 years $^{5}$. The median age was higher in our series, and only one fifth of the patients 
were men. This difference can be explained by the selection of a study group as clinically N0 PTC, because one expects more female and older patients in the group of patients with PTC with N0 lymph node status.

Compared with the series of Machens et al., average tumor size in our series was smaller, the proportion of tumors smaller than $10 \mathrm{~mm}$ was higher, and multifocality was seen in more patients ${ }^{15}$. Although all tumor characteristics differ among published series, tumor multifocality shows the highest variability and is described in up to $85 \%$ of patients 5 .

It has been shown that the number of lymph nodes in the CND specimen is important in predicting central compartment recurrence ${ }^{16}$. The expected number of lymph nodes in the central neck compartment, according to a cadaveric study, is four (range

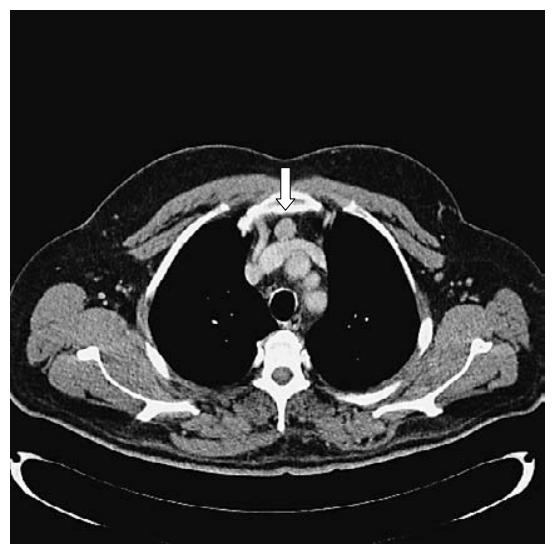

Figure 3. Contrast-enhanced MSCT (arrow points to an enlarged region VII lymphnode).
1-16) ${ }^{17}$. In our series, we found 5.5 nodes per central neck dissection specimen, demonstrating the high quality of dissections.

All studies found greater rates of temporary hypoparathyroidism with $\mathrm{CND}^{6}$. Surgical treatment of thyroid carcinoma is associated with a greater rate of hypoparathyroidism when CND is added to thyroidectomy ${ }^{6}$. Transient hypoparathyroidism appeared in $23.4 \%$ of patients in our series and became permanent in $3.2 \%$ of patients. Our result is comparable to other studies ${ }^{6,18,19}$. Use of different surgical techniques does not change the complication rates significantly ${ }^{20}$.

Ryu et al. showed that male sex, tumor size larger than $1 \mathrm{~cm}$, positive lymph nodes, lymphovascular invasion, and extrathyroidal extension are significantly associated with lateral neck $\mathrm{LN}$ recurrence ${ }^{21}$. Data in our series were consistent with published data - risk of recurrence is doubled for $\mathrm{N} 1$ patients.

Although we are able to recognize tumors with higher metastatic potential after surgery and immunohystochemical analysis, this does not help preoperative decision making. Some authors mention angiogenesis ${ }^{22}$, or more precisely matrix metalloproteinases and their inhibitors, regarding the development of lymph node metastases ${ }^{23}$.

Diagnostic work up can also be improved in order to help the surgeon decide on the optimal operation plan for every patient. After identifying a patient with higher risk of central compartment metastases, multislice computed tomography (MSCT) can be performed (Figure 3). This diagnostic procedure is usually
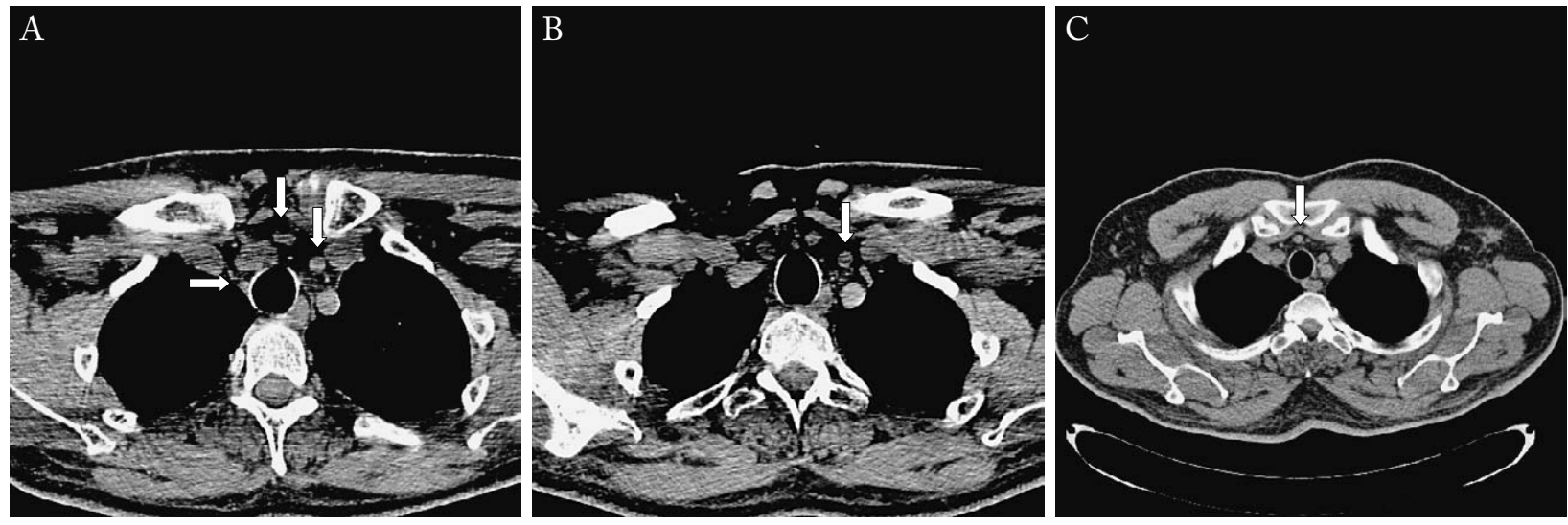

Figure 4. $(A, B, C)$ Non enhanced MSCT. The figure shows good visibility of paratracehal and pretracheal lymphnodes even on a MSCT without intravenous contrast (arrows). 
avoided in patients with PTC because it is in most cases performed using an intravenous contrast agent which, consequently, delays the administration of radioactive iodine (RAI). However, the delay is 4-8 weeks at most, with literature stating that a 4 -week delay is sufficient ${ }^{24}$. This delay should not be considered a contraindication for performing MSCT since the data acquired from the procedure can change patient management. It is an especially important diagnostic procedure for patients with large tumors, tumors with extrathyroidal spread, or patients with widely distributed nodal disease already identified with US. In these patients, MSCT detects possible involvement of not typically affected regions such as mediastinal, infra-clavicular, retropharynegeal and parapharyngeal regions, which cannot be adequately evaluated using US. MSCT is also more accurate in assessing the central compartment ${ }^{25}$, especially region VII which cannot be visualized with US alone. Suspicious lymph nodes in this region seen on MSCT should alter the surgical approach. Furthermore, this particular region can be also adequately assessed using a noncontrast MSCT scan (Figure 4). The anatomy of the region allows an experienced radiologist to detect lymph nodes as small as $3 \mathrm{~mm}$, even without the use of a contrast agent, thus eradicating the need for delay of RAI treatment in patients where it is necessary to administer the RAI treatment as soon as possible.

\section{Conclusion}

In our hands, CND has been a safe and effective surgical procedure. The question that has to be answered is whether it should be indicated in all patients with PTC and whether we can improve preoperative work-up to more accurately identify high-risk patients.

At the moment, CND significantly improves staging and enables more precise postsurgical management of patients with PTS.

Further analyses are necessary to answer whether ipsilateral CND can bring the benefit of better staging without the burden of a rising complication rate.

\section{References}

1. Lim H, Devesa SS, Sosa JA, Check D, Kitahara CM. Trends in Thyroid Cancer Incidence and Mortality in the United States,
1974-2013. JAMA. 2017;317(13):1338-1348. doi:10.1001/ jama.2017.2719

2. Kusić Z, Prgomet D. Karcinom štitne i doštitne žljezde. In: Prgomet D. Tumori glave i vrata. Zagreb: Medicinska naklada. 2019.p. 262-73. Croatian

3. Roman BR, Morris LG, Davies L. The thyroid cancer epidemic, 2017 perspective. Curr Opin Endocrinol Diabetes Obes. 2017; 24(5):332-336. doi:10.1097/MED.0000000000000359

4. Nilubol N, Kebebew E. Should small papillary thyroid cancer be observed? A population-based study. Cancer. 2015;121 (7):1017-1024. doi:10.1002/cncr.29123

5. Sherman SI. Thyroid carcinoma. Lancet. 2003;361(9356): 501-511. doi:10.1016/s0140-6736(03)12488-9

6. Mazzaferri EL, Doherty GM, Steward DL. The pros and cons of prophylactic central compartment lymph node dissection for papillary thyroid carcinoma. Thyroid. 2009;19(7):683-689. doi:10.1089/thy.2009.1578

7. Moreno M, Edeiken-Monroe B, Siegel E, Sherman S, Clayman G 2012 In papillary thyroid cancer, preoperative central neck ultrasound detects only macroscopic surgical disease, but negative findings predict excellent long-term regional control and survival. Thyroid 22:347-355.

8. Leboulleux S, Girard E, Rose M, Travagli JP, Sabbah N, Caillou B, et al. 2007 Ultrasound criteria of malignancy for cervical lymph nodes in patients followed up for differentiated thyroid cancer. J Clin Endocrinol Metab 92:3590-3594.

9. Gambardella C, Tartaglia E, Nunziata A, et al. Clinical significance of prophylactic central compartment neck dissection in the treatment of clinically node-negative papillary thyroid cancer patients. World J Surg Oncol. 2016;14(1):247. Published 2016 Sep 19. doi:10.1186/s12957-016-1003-5

10. Calò PG, Conzo G, Raffaelli M, et al. Total thyroidectomy alone versus ipsilateral versus bilateral prophylactic central neck dissection in clinically node-negative differentiated thyroid carcinoma. A retrospective multicenter study. Eur J Surg Oncol. 2017;43(1):126-132. doi:10.1016/j.ejso.2016.09.017

11. Dubernard X, Dabakuyo S, Ouedraogo S, et al. Prophylactic neck dissection for low-risk differentiated thyroid cancers: Risk-benefit analysis. Head Neck. 2016;38(7):1091-1096. doi: 10.1002/hed.24402

12. Ilhan H, Mustafa M, Bartenstein P, Kuwert T, Schmidt D. Rate of elimination of radioiodine-avid lymph node metastases of differentiated thyroid carcinoma by postsurgical radioiodine ablation. A bicentric study. Nuklearmedizin. 2016;55(6): 221-227. doi:10.3413/Nukmed-0794-16-01

13. He Y, Pan MZ, Huang JM, Xie P, Zhang F, Wei LG. Iodine-131: An Effective Method for Treating Lymph Node Metastases of Differentiated Thyroid Cancer. Med Sci Monit. 2016;22:4924-4928. Published 2016 Dec 15. doi:10.12659/ msm.899028

14. American Thyroid Association (ATA) Guidelines Taskforce on Thyroid Nodules and Differentiated Thyroid Cancer, Cooper DS, Doherty GM, et al. Revised American Thyroid Association management guidelines for patients with thyroid nodules and differentiated thyroid cancer [published correction appears in 
Thyroid. 2010 Aug;20(8):942. Hauger, Bryan R [corrected to Haugen, Bryan R]] [published correction appears in Thyroid. 2010 Jun;20(6):674-5]. Thyroid. 2009;19(11):1167-1214. doi: 10.1089/thy.2009.0110

15. Machens A, Holzhausen HJ, Dralle H. The prognostic value of primary tumor size in papillary and follicular thyroid carcinoma. Cancer. 2005;103(11):2269-2273. doi:10.1002/cncr.21055

16. Heaton CM, Chang JL, Orloff LA. Prognostic Implications of Lymph Node Yield in Central and Lateral Neck Dissections for Well-Differentiated Papillary Thyroid Carcinoma. Thyroid. 2016;26(3):434-440. doi:10.1089/thy.2015.0318

17. Ofo E, Thavaraj S, Cope D, et al. Quantification of lymph nodes in the central compartment of the neck: a cadaveric study. Eur Arch Otorbinolaryngol. 2016;273(9):2773-2778. doi:10.1007/s00405-015-3827-y

18. Radivojević RC, Prgomet D, Markesić J, Ezgeta C. Hypocalcaemia after thyroid surgery for differentiated thyroid carcinoma: preliminary study report.Coll Antropol. 2012 Nov;36 Suppl 2:73-8.

19. Grabovac S, Prgomet D, Janjanin S, Hadzibegović AD. Parathyroid hormone values in thyroid gland surgeries by harmonic scalpel and by conventional methods]. Lijec Vjesn. 2013 NovDec;135(11-12):306-10.

20. Prgomet D, Janjanin S, Bilić M, Prstacić R, Kovac L, Rudes M, Katić V. A prospective observational study of 363 cases oper- ated with three different harmonic scalpels. Eur Arch Otorhinolaryngol. 2009 Dec;266(12):1965-70.

21. Ryu YJ, Kang SJ, Cho JS, Yoon JH, Park MH. Identifying risk factors of lateral lymph node recurrence in clinically node-negative papillary thyroid cancer. Medicine (Baltimore). 2018;97 (51):e13435. doi:10.1097/MD.0000000000013435

22. Stabenow E, Tavares MR, Ab'Saber AM, et al. Angiogenesis as an indicator of metastatic potential in papillary thyroid carcinoma. Clinics (Sao Paulo). 2005;60(3):233-240. doi:10.1590/ s1807-59322005000300009

23. Bumber B, Marjanovic Kavanagh M, Jakovcevic A, Sincic N, Prstacic R, Prgomet D. Role of matrix metalloproteinases and their inhibitors in the development of cervical metastases in papillary thyroid cancer. Clin Otolaryngol. 2020 Jan;45(1): 55-62.

24. Padovani RP, Kasamtsu TS, Nakabashi CC, Camacho CP, Andreoni DM et al. 2012 One month is sufficient for urinary iodine to return to its baseline value after the use of water-soluble contrast agents in post-thyroidectomy patients requiring radioiodine therapy. Thyroid 22:926-930.

25. Lednik D, Cunnane ME, Zurakowski D, ACAR GO, Mace A, Kamani D, et al. 2014 Papillary thyroid carcinoma nodal surgery directed by a preoperative radiographic map utilizing CT scan and ultrasound in all primary and reoperative patients. Head Neck 36:191-202.

Sažetak

\section{TOTALNA TIROIDEKTOMIJA S DISEKCIJOM CENTRALNE REGIJE VRATA U LIJEČENJU PAPILARNOG KARCINOMA ŠTITNJAČE}

\section{Pastorčić Grgič, B. Stubljar, P. Perše, M. Zekan Vučetić i S. Šitić}

Uvod: Papilarni karcinom štitnjače spada u tumore s povoljnom prognozom unatoč opisivanoj stopi recidiva u paratrahealnoj regiji i do $30 \%$ slučajeva. Radiojodna ablacija se smatra pouzdanom metodom liječenja metastaza u paratrahealnim čvorovima. Većina međunarodno prihvaćenih smjernica ne preporuča rutinsko izvođenje disekcije regije VI (CND) već se samo totalna tireidektomija (TT) smatra adekvatnim liječenjem u ovoj skupini bolesnika. Prema mnogim studijama CND je povezana s višom pojavnošću hipoparatireoidizma. S druge strane, CND pomaže u utvrđivanju točnog staginga bolesti. Metode: Proveli smo retrospektivnu studiju u koju smo uključili 248 bolesnika koji su liječeni zbog papilarnog karcinoma štitnjače tijekom 20 godina. Podaci su analizirani temeljem karakteristika bolesnika (dob, spol), tumora (veličina, uni - i mutifokalnost), prisustva metastaza u centralnoj regiji vrata, incidencije postoperativnog hipoparatireoidizma i stope lokoregionalnog povrata bolesti. Na osnovu patohistološkog nalaza podijelili smo bolesnike u dvije skupine: bolesnike bez pozitivnih limfnih čvorova u regiji VI (N0 skupina) kao i one s pozitivnim limfnim čvorovima u regiji VI (N1 skupina). Uspoređivali smo osobine bolesnika i karakteristike tumora kao i rizik lokalnog recidiva bolesti između ove dvije skupine. Rezultati: U našoj seriji bilo je $39.5 \%$ bolesnika s metastazama u regiji VI vrata čiji su disektati u prosjeku sadržavali 5.5 limfnih čvorova. Postoperativni hipoparatireoidizam je verificiran kod 23.4\% bolesnika, a ostao trajan u 3.2\% bolesnika. Žene i bolesnici starije životne dobi imali su manji rizik od metastaza u regiju VI, isto kao i bolesnici s manjim i unifokalnim tumorima. Rizik povrata bolesti bio je udvostručen za N1 skupinu bolesnika. Sve analizirane razlike između skupina pokazale su statističku značajnost. Rasprava $i$ zaključak: U našoj ustanovi CND smatramo sigurnom i učinkovitom operacijom koja poboljšava staging bolesti i time unapređuje daljnje liječenje bolesnika. Nužno je poboljšati preoperativnu obradu kako bismo prepoznali bolesnike visokog rizika.

Ključne riječi: papilarni karcinom, disekcija regije VI 